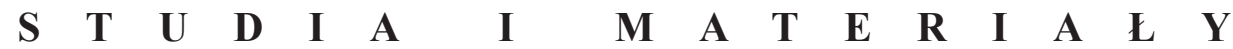

ARCHEION, T. CXX

WARSZAWA 2019

ISSN 0066-6041

e-ISSN 2658-1264

DOI 10.4467/26581264ARC.19.008.11817

BARBARA BERSKA

ORCID $\underline{0000-0002-9391-2273}$

barberska@gmail.com

(Archiwum Narodowe w Krakowie)

\section{POLSKA JEST NAPRAWDĘ! KRAKÓW JEST POLSKI! ŹRÓDŁA DO BADAŃ KWESTII ODZYSKANIA NIEPODLEGŁOŚCI PRZEZ KRAKÓW PRZECHOWYWANE W ARCHIWUM NARODOWYM W KRAKOWIE}

Słowa kluczowe: Archiwum Narodowe w Krakowie, Archiwum Aktów Dawnych Miasta Krakowa, Adam Chmiel, I wojna światowa, materiały ikonograficzne

\section{Streszczenie}

Przypadająca w 2018 r. setna rocznica odzyskania przez Polskę niepodległości i przywrócenia jej po 123 latach na mapy polityczne Europy jest chętnie podejmowanym tematem badawczym wśród historyków, regionalistów, uczniów. Istotnym zatem wydaje się wskazanie źródeł do badań tych zagadnień w jednym z największych polskich archiwów, w Archiwum Narodowym w Krakowie.

W Archiwum Narodowym w Krakowie zachowało się wiele dokumentów, na podstawie których można badać, a nawet odtworzyć wiele wydarzeń związanych z odzyskaniem niepodległości przez Kraków. Wydarzenie to jest bardzo dobrze udokumentowane m.in. dzięki zainteresowaniom oraz działaniom podjętym przez ówczesnego dyrektora Archiwum Aktów Dawnych Miasta Krakowa dr. Adama Chmiela. Niezmiernie ciekawy materiał badawczy stanowią różnego rodzaju meldunki, poświadczenia przejęcia przez polską komendę obiektów o znaczeniu strategicznym, jak dworce, koszary, szpitale, straż pożarna, a także raporty poszczególnych formacji składane do Komendy miasta. Innym ciekawym źródłem do badań są pamiętniki, będące żywym komentarzem do wydarzeń - często bieżącą relacją. Bardzo cenny materiał źródłowy do badań dają nam spuścizny. Komplementarne względem dokumentów aktowych są też fotografie przechowywane w Zbiorze fotograficznym czy też plakaty, afisze, odezwy, obwieszczenia, zawiadomienia, ogłoszenia zgromadzone w Zbiorze afiszy i plakatów. 


\section{POLAND REALLY EXISTS! CRACOW IS POLISH! SOURCE MATERIALS FOR RESEARCH CONCERNING THE ISSUE OF RESTORATION OF INDEPENDENCE IN CRACOW, PRESERVED IN THE NATIONAL ARCHIVE IN CRACOW}

Keywords: National Archive in Cracow, Cracow Archive of Historical Records, Adam Chmiel, World War I, iconographic materials

\footnotetext{
Abstract

The 2018 centenary of restoration of Poland's sovereignty and the country's reinstatement on the political map of Europe after 123 years is a popular research topic among historians, regionalists and students. Therefore, it seems important to indicate source materials for research on the subject in one of the largest Polish archives, the National Archive in Cracow.

In the National Archive in Cracow, many documents allowing for investigation and even reconstruction of a number of events related to the restoration of independence in Cracow have been preserved. The event is very well documented thanks to, inter alia, the interests and actions of the then Director of the Cracow Archive of Historical Records, Dr Adam Chmiel. The extraordinarily interesting research material comprises various types of reports, testimonies of takeover of structures of strategic importance, such as railway stations, barracks, hospitals, fire brigades by the Polish command, as well as reports of individual formations submitted to the City Command. Another interesting source for research on this issue are the diaries, which are a lively and often current account of events. Legacies also constitute invaluable source material for research. Complementary to the file documents are the photographs stored in the Photographic Collection as well as posters, broadsides, proclamations, announcements, notices, preserved in the Posters and Broadsides Collection.
} 
Przypadająca w 2018 r. setna rocznica odzyskania przez Polskę niepodległości i przywrócenia jej po 123 latach na mapy polityczne Europy jest chętnie podejmowanym tematem badawczym wśród historyków, regionalistów, uczniów. Święto odzyskania niepodległości utożsamiane jest najczęściej z datą 11 listopada, która oznacza - w wymiarze szerszym - zakończenie działań zbrojnych na frontach I wojny światowej, a dla ziem polskich stworzenie jednego ośrodka władzy państwowej w Warszawie, po przekazaniu przez Radę Regencyjną w tym dniu władzy wojskowej Józefowi Piłsudskiemu. Do Krakowa ta wolność zawitała jednak wcześniej. Miasto zrzuciło obce panowanie jako jedno z pierwszych na ziemiach polskich ${ }^{1}$.

Tematyka ta obecna jest w literaturze, powstało wiele wartościowych publikacji traktujących o problemie usunięcia Austriaków z zachodniej części Galicji, szczególnie z Krakowa. Wnikliwie i obszernie temat został przedstawiony w pracach Ludwika Mroczka Galicji rozstanie z Austria. Zarys monograficzny (wydanej w Krakowie w 1990) i Spór o Galicję Wschodnia 1914-1923 (wydanej w Krakowie w 1998), Piotra Łossowskiego Jak feniks z popiołów. Oswobodzenie ziem polskich spod okupacji w listopadzie 1918 (wydana w Lowiczu w 1998) i wydanej zaledwie w kilka lat po wydarzeniach roku 1918 pozycji Adama Chmiela Oswobodzenie Krakowa 31 października 1918 roku (wydana w Krakowie w 1929). Najnowsza publikacja w tym zakresie, to Wieża Wolności 1918. W 100. rocznice wyzwolenia Krakowa, album autorstwa Jana T. Nowaka (wydany w Krakowie w 2018). Problematykę tę podnosili też: Józef Buszko², Michał Śliwa ${ }^{3}$ czy Marek Przeniosło w ciekawej publikacji Polska Komisja Likwidacyjna 1918-1919 (wydanej w Kielcach w 2010).

$\mathrm{W}$ prowadzonych badaniach istotne też zapewne będą drukowane materiały źródłowe, jak choćby Narodziny niepodległości Galicji (1918-1919). Wybór źródeł $z$ archiwów lwowskich, opracowane przez Marka Przeniosło (wydane w Kielcach w 2007), czy wspomnienia uczestników tych wydarzeń: Antoniego Stawarza ${ }^{4}$, Bolesława Roi ${ }^{5}$, Karola Estreichera ${ }^{6}$ i Klemensa Bąkowskiego ${ }^{7}$ oraz

${ }^{1}$ Artykuł był zaprezentowany w skróconej formie w trakcie konferencji pt. „Archiwa Niepodległej. Źródła do badań odzyskiwania przez Polskę niepodległości w archiwach państwowych”, zorganizowanej przez Naczelną Dyrekcję Archiwów Państwowych w Warszawie w dniach 20-21 września 2018 r. W tytule zacytowano wpis z 31 października 1918 r. Dziennika Klemensa Bąkowskiego, zob.: Biblioteka Jagiellońska, rkps 7285, Dziennik Klemensa Bąkowskiego, z. 13, k. 13v.

2 J. Buszko, Polska Komisja Likwidacyjna, [w:] Problemy historii Stowian i Europy Środkowej w XIX i XX wieku. Zbiór studiów, Wrocław 1982, s. 25-37.

${ }^{3}$ M. Śliwa, Pierwsze ośrodki władzy polskiej w Galicji w 1918 r., „Dzieje Najnowsze” 1988, nr 4, s. $63-73$.

${ }^{4}$ A. Stawarz, Gdy Kraków kruszył pęta. Kartki z pamiętnika oswobodzenia Krakowa w 1918 r., wstępem i objaśnieniami opatrzył J. Czapliński, Kraków 1939.

${ }_{5}^{5}$ B. Roja, Legendy i fakty, Warszawa 1931.

${ }^{6}$ K. Estreicher, Nie od razu Kraków zbudowano, Warszawa 1956.

7 K. Bąkowski, Kronika Krakowa od 1918 do 1923, Kraków 1925. 
członków Polskiej Komisji Likwidacyjnej (dalej: PKL) Zygmunta Lasockiego ${ }^{8}$, Wincentego Witosa ${ }^{9}$, Ignacego Daszyńskiego ${ }^{10}$, Hermana Diamanda ${ }^{11}$. Wspomnienia uczestników zostały opublikowane również w pracy Listopad 1918 we wspomnieniach i relacjach (wybór, oprac. i wstęp Piotra Łossowskiego i Piotra Staweckiego, wydane w Warszawie 1988) i w artykule Kazimierza Przybosia Dwie relacje Tadeusza Szantrocha - o Krakowie w 1914 i o oswobodzeniu Krakowa 31 października 1918 roku („Rocznik Krakowski” 1987, t. 53, s. 158).

Istotnym zatem wydaje się wskazanie źródeł do badań tych zagadnień w jednym z największych polskich archiwów, w Archiwum Narodowym w Krakowie (dalej: ANK).

Już 31 października 1918 r., gdy wojna jeszcze trwała i wszystkie ziemie polskie znajdowały się pod władzą lub okupacją wojskową państw centralnych, w Krakowie zawisły flagi w barwach narodowych, a żołnierze Polacy objęli władzę wojskową w mieście. W odwachu pod wieżą ratuszową dokonała się przełomowa zmiana warty - austriackiej na polską. To właśnie ta wieża, 31 października 1918 r., była pierwszym promieniem wolnej Polski, a Kraków pierwszym miastem, w którym po latach obcego władztwa zapanowała wolność.

Ale zanim to nastąpiło, w gmachu krakowskiego Magistratu zasiadła, jako najwyższa urzędująca władza dla Galicji, Polska Komisja Likwidacyjna powołana w celu likwidacji władzy austriackiej. Utworzyło ją 28 października 23 polskich posłów do parlamentu austriackiego i Sejmu Krajowego, reprezentujących rozmaite stronnictwa polityczne - od konserwatystów po socjalistów. Na czele stało czteroosobowe tymczasowe prezydium, w skład którego weszli: Ignacy Daszyński ${ }^{12}$ - socjalista, poseł z Krakowa, Wincenty Witos ${ }^{13}$ (Polskie Stronnictwo Ludowe), Aleksander Skarbek ${ }^{14}$ (Narodowa Demokracja) i Tadeusz Tertil ${ }^{15}$ (Polska Demokracja). Polska Komisja Likwidacyjna rozciągnęła swoją władzę na całą Galicję Zachodnią, a w zamiarze - na cały zabór austriacki.

Mimo iż Galicja, a z nią Kraków, formalnie zerwała związki z monarchią, pozostała jeszcze istotna kwestia zapanowania nad stacjonującym w mieście gar-

${ }^{8}$ Z. Lasocki, Wspomnienia szefa administracji P.K.L. I K. Rz., Kraków 1931.

${ }_{9}$ Moje wspomnienia. Wincenty Witos, do druku przygotowali, przedmową i przypisami opatrzyli E. Karczewski, J.R. Szaflik, cz. 1, Warszawa 1998.

${ }^{10}$ I. Daszyński, Pamiętniki, t. 1, Kraków 1925.

${ }^{11}$ Pamiętnik Hermana Diamanda, zebrany z wyjątków listów do żony, wstęp S. Loewenstein, Kraków 1932.

${ }^{12}$ Biogram Ignacego Daszyńskiego (1866-1936), [w:] Polski stownik biograficzny (dalej: PSB); hasło oprac. J. Feldman, t. 4, Kraków 1938, s. 448-454.

${ }^{13}$ Wincenty Witos (1874-1945), polityk, działacz ruchu ludowego, trzykrotny premier Rzeczypospolitej Polskiej, poseł do galicyjskiego Sejmu Krajowego, poseł do austriackiej Rady Państwa.

${ }^{14}$ Biogram Aleksandra Skarbka (1974-1922), [w:] PSB; hasło oprac. E. Orman, t. 38, Warszawa-Kraków 1997-1998, s. 17.

${ }^{15}$ Tadeusz Tertil (1864-1925), prawnik, burmistrz Tarnowa, poseł do Rady Państwa w Wiedniu i Sejmu Krajowego Galicji, członek PKL, założyciel Unii Narodowo-Państwowej (1922). 
nizonem austriackim, liczącym około 12 tys. żołnierzy, przeważnie narodowości niemieckiej, węgierskiej i ukraińskiej ${ }^{16}$. Potrzebą chwili stało się też niedopuszczenie do wywiezienia z Krakowa gromadzonych od początku wojny zapasów żywności i broni o wartości sięgającej milionów koron. W zaistniałej sytuacji polskim komendantem wojskowym mianowano zamieszkałego wówczas w Krakowie płk. Bolesława Roję ${ }^{17}$, byłego dowódcę 4. pułku piechoty Legionów. Jak miały pokazać następne godziny, siłą sprawczą nadchodzących wydarzeń był jednak nie płk Roja, ale mało wówczas znany por. Antoni Stawarz ${ }^{18}$, który dzięki współpracy z kolejarzami krakowskimi spowodował powstrzymanie wysyłki transportów, m.in. z żywnością za granicę. Wcześniej wykazał się olbrzymią odwagą i determinacją, przejmując koszary przy ul. Kalwaryjskiej ${ }^{19}$ - bez jednego wystrzału. Następnie z Rynku Podgórskiego kompanie rozbrojonych żołnierzy oraz podgórzan rozpoczęły swój marsz w stronę Rynku Głównego, gdzie komendant warty złożonej z 15 piechurów, w trybie austriackiego regulaminu, bez oporu przekazał odwach polskiemu dowództwu. W asyście wiwatujących tłumów zrzucono austriackiego orła i portrety cesarskie, przystrajając gmach w narodowe barwy ${ }^{20}$.

W tym samym dniu, 31 października, w gmachu Magistratu odbyło się posiedzenie komisji wojskowej, której członkowie dotarli na miejsce obrad w atmosferze i przy świadomości mających miejsce wypadków „zdzierania żołnierzom i oficerom orzełków tzw. bączków”. Przebieg tego, jakże burzliwego spotkania, znany jest m.in. z przechowywanej w ANK relacji jego uczestnika, urzędnika Magistratu, wiceprezesa „Sokoła” Edwarda Kubalskiego ${ }^{21}$. Komendant twierdzy gen. Siegmund Benigni ${ }^{22}$ wraz z szefem sztabu generalnego płk. Ludwikiem Grimmem i gen. intendentem Zaretzkym spotkali się z przedstawicielami PKL Aleksandrem Skarbkiem i Zygmuntem Lasockim ${ }^{23}$.

${ }_{16}$ J.T. Nowak, Wieża Wolności 1918. W 90. rocznicę wyzwolenia Krakowa, Kraków 2008, s. 21.

${ }^{17}$ Biogram Bolesława Roi (1876-1940), [w:] PSB; hasło oprac. H. Korczyk, t. 31/4, z. 131, Wrocław-Warszawa-Kraków 1989, s. 508-511.

${ }_{18}$ Biogram Antoniego Stawarza (1889-1955), [w:] PSB; hasło oprac. A. Kostrzewski, t. 42/4, z. 175, Warszawa-Kraków 2004, s. 601-602.

${ }^{19}$ Koszary austriackie przy ul. Kalwaryjskiej w Podgórzu, gdzie stacjonowały wojska kawalerii. 31 października 1918 r. doszło tu do bezkrwawego rozbrojenia stacjonujących w nich żołnierzy armii austriackiej. Obecnie na ich miejscu znajduje się plac Niepodległości.

${ }^{20}$ J.T. Nowak, op.cit. s. 55-64.

${ }^{21}$ Biogram Edwarda Kubalskiego (1872-1958), [w:] PSB; hasło oprac. K. Toporowicz [online] Warszawa: Narodowy Instytut Audiowizualny, http://www.ipsb.nina.gov.pl/a/biografia/edward-kubalski [dostęp: 10.12.2018].

22 Siegmund Benigni, wł. Siegmund Rotter von Benigni in Muldenberg (1858-1922), w początkach I wojny światowej dowódca 54. Dywizji Piechoty walczącej w Galicji Wschodniej, następnie dowodził 15. Dywizją Piechoty, operującą w Karpatach, potem VIII Korpusem (do marca 1918). Od marca do października 1918 r. był dowódcą twierdzy Kraków.

${ }^{23}$ Biogram Zygmunta Lasockiego (1867-1948), [w:] PSB; hasło oprac. A. Szklarska-Lohmannowa, t. 16, Wrocław-Warszawa-Kraków-Gdańsk 1971, s. 551-554. 
Skarbek zwrócił się z apelem do swych rozmówców: „W imieniu Rządu polskiego wzywam panów, abyście w nasze ręce złożyli swoją władzę"24. Po burzliwych pertraktacjach, prowadzonych od rana w Magistracie przez PKL, poseł Skarbek wygłosił formułę, iż przybyły na obrady „Brygadyer Roja obejmuje komendę, którą nam Panowie oddacie". Po bezskutecznych próbach oponowania, w poczuciu bezsilności, gen. Benigni przekazał swe kompetencje władzom polskim.

Jak pisał Kubalski: „o godzinie 2giej powrócił do gmachu Magistratu pułkownik Roja - mógł już stwierdzić, że władza wojskowa i wszystkie obiekty najważniejsze przeszły w ręce Komendy polskiej. $Z$ tą chwilą dalsze zatrzymywanie panów wojskowych austriackich stało się zbyteczne. To też po podpisaniu wspomnianego układu odwieziono ich - na ich prośbę automobilem pod opieką polskich oficerów do ich domów. Tak skończył się zamach stanu w Krakowie a rozpoczęła się praca około budowy własnej polskiej państwowości, polskiego rządu i polskiej armii" 25 .

Istotnie z rozkazu Polskiego Komitetu Likwidacyjnego płk Roja obją z dniem 1 listopada 1918 r. „Komendę Wojskową w Krakowie na obszarze galicyjskim od polnego zbrojmistrza Ekscelencyi hr. Benigniego"26.

Przejęcie pełni władzy w Krakowie w 1918 r. miało duże znaczenie przede wszystkim moralne. Wydarzenia krakowskie wpłynęły znacząco na proces odzyskiwania niepodległości w Galicji Zachodniej oraz na terenach Królestwa zajętych przez armię austriacką (Kielecczyzna, Lubelszczyzna). Do tej chwili przygotowywało się wiele krakowskich ośrodków konspiracyjnych, ale dopiero determinacja kilku młodych oficerów na czele z por. Antonim Stawarzem sprawiła, że osiągnięto wymarzony cel. Dzięki ich zdecydowaniu i przemyślanemu planowi działania, obeszło się bez zbędnej walki, strat ludzkich, zniszczeń materialnych.

Generał Marian Kukiel ${ }^{27}$, znakomity historyk, opisał po latach czyn Stawarza w sposób niezwykle trafny: „W nocy z 30 na 31 października z kilkoma kolegami i garścią swych tarnowiaków przypiął kokardy narodowe, opanował koszary batalionów asystencyjnych na Podgórzu, Polaków i Czechów przeciągnął na swą stronę, Niemców rozbroił, oficerów obcych internował, opanował jeszcze koszary artylerii, wysłał patrole na miasto, odkomenderował oddział do zajęcia odwachu, postarał się sterroryzować wiadomością

\footnotetext{
${ }^{24}$ Archiwum Narodowe w Krakowie (dalej: ANK), 29/667/0 Prace naukowe, literackie i pamiętniki - zbiór szczątków zespołów 1401-2002, sygn. 29/667/28, s. 3.

${ }^{25}$ Ibidem, s. 11. Zob. też: E. Kubalski, Kraków w czasie Wielkiej Wojny, wstęp i red. nauk. M. Zakrzewski, Kraków 2018, s. 119.

${ }^{26}$ ANK, 29/669/0 Varia publica - zbiór szczątków zespołów 1502-1972, sygn. 29/669/21, Rozkaz polskiego Dowództwa wojskowego nr 1 wydanego w Krakowie w dniu 1 listopada $1918 \mathrm{r}$.

${ }^{27}$ Marian Kukiel (1885-1973), gen. dyw. PSZ, historyk wojskowości, działacz społeczny, polityk, wykładowca uniwersytecki, żołnierz pierwszej Brygady Legionów Polskich. Od grudnia 1918 r. zastępca Szefa Sztabu Generalnego WP.
} 
o fakcie dokonanym władze i pobudzić żołnierzy polskich całej załogi Krakowa i okręgu do wystąpienia. Zrobił to co Wysocki w Noc Listopadową, a zrobił szczęśliwie" 28 .

W Archiwum Narodowym w Krakowie zachowało się wiele dokumentów, na podstawie których można badać, a nawet odtworzyć wydarzenia zaistniałe 31 października 1918 r. i w kolejnych listopadowych dniach. Odzyskanie niepodległości przez Kraków, zwane też przewrotem, jest bardzo dobrze udokumentowane, m.in. dzięki zainteresowaniom oraz działaniom podjętym przez ówczesnego dyrektora Archiwum Aktów Dawnych Miasta Krakowa dr. Adama Chmiela ${ }^{29}$. Na początku lat 20. XX w. rozpoczął akcję zbierania dokumentów oraz wszelkich pamiątek, a nade wszystko spisywanych relacji uczestników przewrotu. Niewielki upływ czasu od wydarzeń w 1918 r. i rejestrowania relacji pozwala traktować te wspomnienia jako wiarygodny i niezwykle ciekawy materiał badawczy. Oprócz opisu zdarzeń, możemy odczytać różnego rodzaju animozje między uczestnikami, pogłębiające się z upływem czasu, wielość punktów widzenia, nawet wręcz skrajnych. Każda jednak jest autentyczna i spisana przez rzeczywistego uczestnika zdarzeń krakowskich z przełomu października i listopada 1918 r. Sposób na pozyskiwanie tych dokumentów był różny, odgrywały tu olbrzymią rolę przede wszystkim osobiste kontakty dr. Chmiela, ale też ogłoszenia prasowe kierowane do uczestników, zamieszczane w różnych tytułach prasowych ${ }^{30}$, w pewnych odstępach czasowych. Ten sposób pozyskiwania dokumentów był również wykorzystywany w latach późniejszych ${ }^{31}$. W omawianych materiałach zgromadzono ponadto: niekompletne rozkazy Polskiego Dowództwa Wojskowego, rozkazy Komendy miasta (druki, rękopisy i maszynopisy), rękopis opublikowanego w 1929 r. Oswobodzenia Krakowa 31 października 1918 r., autorstwa Adama Chmiela, karty służbowe wydane przez Komendę miasta ${ }^{32}$. Niezmiernie ciekawy materiał badawczy stanowią różnego rodzaju meldunki, poświadczenia przejęcia przez polską komendę obiektów o znaczeniu strategicznym, jak dworce, koszary, szpitale, straż pożarna ${ }^{33}$, a także raporty poszczególnych formacji składane do

${ }^{28}$ M. Kukiel, W piętnastolecie wyzwolenia Krakowa, „Kurier Warszawski” 1933, nr 301 z 31 października, cyt. za: J.T. Nowak, op.cit., s. 157.

${ }^{29}$ Biogram Adama Chmiela (1865-1934), [w:] PSB; hasło oprac. K. Kaczmarczyk, t. 3, Kraków 1937, s. 316-317.

${ }^{30}$ Zob. anonse zamieszczone w „Rzeczpospolitej” (nr 38 z 8 lutego 1923 r.) i „Ilustrowanym Kuryerze Codziennym” (nr 21 z 1 sierpnia 1928 r.).

31 Ówczesne Archiwum Państwowe w Krakowie przeprowadziło zbiórkę dokumentów związanych z wydarzeniami końca października 1918 r. w ich 50. rocznicę. Podobne akcje zakończone sukcesem przeprowadziło też Muzeum Miasta Krakowa.

${ }^{32}$ Wszystkie dokumenty tematycznie związane z odzyskaniem niepodległości przez Kraków, zebrane przez Adama Chmiela, przechowywane są w zbiorze archiwalnym ANK, 29/669/0 Varia publica - zbiór..., sygn. 29/669/21.

${ }^{33}$ Ibidem, np. s. 947, 981, 953. 
Komendy miasta ${ }^{34}$. W zgromadzonych materiałach do relacji uczestników zostały dołączone ich fotografie, zachowało się nawet zdjęcie pokoju, „w którym podpisywano oddanie miasta" 35 . Wspomniane relacje i sprawozdania uczestników przewrotu to uporządkowane alfabetycznie dokumenty, sporządzone przez m.in. Klemensa Bąkowskiego, Juliana Gertlera, Karola Hallera, Ludwika Iwaszkę, Edwarda Kubalskiego, Zygmunta Lasockiego, Henryka Pachońskiego, Karola Rolle, Aleksandra Skarbka, Antoniego Stawarza, Włodzimierza Tetmajera. Zachowały się również dokumenty proweniencji wojskowej, jak: rozkaz Komendy Wojsk Polskich z 1 listopada 1918 r., wzywający wszystkich oficerów bez przydziału do stawienia się w Adiutanturze Komendy Wojskowej $^{36}$, karty służbowe z prośbą o przydział uzupełnień ${ }^{37}$, karty ewidencyjne oficerów, m.in. Antoniego Stawarza, Jana Banacha, Wilhelma Steca ${ }^{38}$. Wraz $\mathrm{z}$ wymienionymi dokumentami przechowywane są też akta stanowiące cenny materiał badawczy do zagadnienia upamiętniania wydarzenia, jakim było odzyskanie niepodległości. Są to m.in.: spis członków Związku Uczestników Oswobodzenia Krakowa, kwestionariusze członków, statut Związku istniejącego faktycznie od 1919 r., choć statutowo zatwierdzonego w 1924 r. Celem Związku było przede wszystkim upamiętnianie wydarzenia z 31 października 1918 r., zrzeszanie jego uczestników, „tworzenie wszelkiego rodzaju dzieł podnoszących ten akt patriotyzmu" 39 . Jego prezesem został Henryk Pachoński, a spisana przez niego historia Związku została wydrukowana w przedmowie do cytowanej już publikacji Adama Chmiela.

Dyrektor Chmiel przejął 21 lutego 1929 r. do zbiorów Archiwum Aktów Dawnych Miasta Krakowa Księgę raportową warty głównej z r. 1918 ${ }^{40}$. Jest to jedna $\mathrm{z}$ tych ksiąg, do których wpisywano codziennie przejmowanie i zdawanie warty na odwachu. Obejmuje ona raporty z okresu od 2 września do 12 listopada 1918 r., choć, jak stwierdził Chmiel, brak dwóch kart między 31 października a 3 listopada. O swoim odkryciu poinformował już następnego dnia ppłk. Jana Kostrzewskiego, komendanta placu w Krakowie ${ }^{41}$. „Brakuje więc w tej księdze raportu zdawczego z dnia 31 października 1918 warty austrjackiej do rąk warty oswobadzającej Kraków spod zaboru austrjackiego z oficerami: Stecem, Gawronem i Zajączkowskim, dalej raportu z dnia 1 i 2 listopada 1918 roku. Że raporta te znajdowały się $\mathrm{w}$ tej księdze świadczy (obok relacji pisemnej ppor.

\footnotetext{
34 Ibidem, np. s. 971, 973, 975, 981.

35 Ibidem, s. 1304.

36 Ibidem, s. 989-995.

37 Ibidem, s. 1065.

38 Ibidem, s. 1149 i n.

39 A. Chmiel, Oswobodzenie Krakowa 31 października 1918 roku, Kraków 1929, s. XVI.

40 ANK, 29/33/0 Akta Miasta Krakowa [1227] 1300-1945 [1975], sygn. 29/33/0/3.1.20/IT 924 Akta wojenne Magistratu miasta Krakowa, fasc. II, Księga raportowa warty głównej z r. 1918 przekazana A. Chmielowi w 1929 r. przez Komendanta Garnizonu w Krakowie.

41 Ibidem, s. 1-3.
} 
Gawrona, która znajduje się w Archiwum ${ }^{42}$ ) etykieta przyklejona na grzbiecie książki - dana już niewątpliwie w polskiej komendzie miasta, na której wypisano: 1 XI-12 XI 1918"43.

Niestety, archiwum Polskiej Komisji Likwidacyjnej zachowało się w ANK dość fragmentarycznie ${ }^{44}$. Zapewne mogłoby ono dopełnić obrazu wydarzeń. Niewielka - bo licząca zaledwie pięć jednostek - część akt tej instytucji przechowywana jest w zespole krakowskiego Archiwum Urzędu Wojewódzkiego. Są to akta wydziałów aprowizacyjnego oraz rolnictwa, a sprawy zgromadzone w jednostkach dotyczą głównie zakazu wywozu towarów, regulacji obrotu bydłem, płodami rolnymi. Pojedyncze materiały w postaci ulotek, afiszy odnaleźć można w spuściznach archiwalnych oraz w Zbiorze afiszy i plakatów. Korespondencja prowadzona pomiędzy PKL a krakowskim Magistratem zachowała się fragmentarycznie, m.in. w Aktach miasta Krakowa. Dotyczą one głównie spraw porządkowych na terenie miasta, kwestii aprowizacyjnych, zakazu wywozu towarów z Krakowa.

Analiza materiałów daje obraz trudności, z jakimi borykała się młoda polska administracja. Komendzie wojskowej udało się szybko opanować panujący w mieście chaos, wywołany zmianą rządów oraz kończącej się wojny. Władze miejskie podjęły żmudne działania na rzecz przystosowania miasta do nowych okoliczności i zapewnienia mieszkańcom należytych warunków życia w trudnej sytuacji przejściowej. Mieszkańcom długo jeszcze przyszło walczyć z dającymi się we znaki uciążliwościami stanu powojennego. Starano się o zwalczanie spekulacji, m.in. przez wprowadzanie kontroli cen. Utrzymywano nadal reglamentację podstawowych artykułów żywnościowych, ale nawet przy tym występowały poważne ich niedobory. Warunki życia codziennego były niezwykle trudne, w mieście panował głód, brak było przede wszystkim chleba, kwitła spekulacja żywnością. Ponadto ludność cywilną nękały w dalszym ciągu choroby zakaźne, niepokój budziły przejawy bandytyzmu ${ }^{45}$. Mimo tych trudności życie codzienne w powojennym Krakowie stopniowo się normalizowało.

\footnotetext{
${ }^{42}$ Relacja taka istotnie się zachowała, jest to list J. Gawrona do H. Pachońskiego z 9 lutego 1923 r., przechowywany w ANK, 29/669/0 Varia publica - zbiór..., sygn. 29/669/21, s. 921.

${ }^{43}$ List dyrektora Chmiela do Komendanta Placu w Krakowie ppłk. Jana Kostrzewskiego z dnia 22 lutego 1929 r., L. 49/29, przechowywany wraz z Księgą raportową warty głównej z r. 1918 w ANK, 29/33/0 Akta Miasta Krakowa..., sygn. 29/33/0/3.1.20/IT 924 Akta wojenne..., fasc. II, s. 1.

${ }^{44}$ Najbardziej obszerna część zespołu Polska Komisja Likwidacyjna w Krakowie (451 j.a.) zachowała się w Centralnym Państwowym Historycznym Archiwum Ukrainy we Lwowie. Wiele zespołów komplementarnych względem zasadniczego zespołu przechowywane są w: Lwowskim Państwowym Archiwum Obwodowym, Centralnym Archiwum Wojskowym, Archiwum Akt Nowych, Archiwum Narodowym w Krakowie (poza wymienionymi jednostkami, materiały przechowywane w oddziałach w Tarnowie i Nowym Sączu), Archiwum Państwowym w Przemyślu i Archiwum Państwowym w Rzeszowie.

${ }^{45}$ Kraków w latach 1918-1939, Dzieje Krakowa, pod. red. J. Bieniarzówny, J.M. Małeckiego, t. 4, Kraków 1997, s. 7-8.
} 
Szczególnie dobrze oddają panujące nastroje sprawy zgromadzone w aktach zespołu C.K. Policji w Krakowie z lat 1849-1919. Końcówka zespołu to akta prowadzone już przez polską policję. Najczęściej są to kontynuacje rozpoczętych przez C.K. Policję w Krakowie spraw ${ }^{46}$. Stanowią one swego rodzaju egzemplifikację tego bezkrwawego, bezstratnego przejęcia władzy, jaka dokonała się w mieście.

W celu utrzymania ładu i porządku w mieście w dniu 1 listopada 1918 r. prezydent Krakowa utworzył Straż Obywatelską. Prezydium miasta wyznaczyło na komendanta Straży dr. Ludwika Schneidra. Miasto zostało podzielone na okręgi odpowiadające jednej bądź kilku dzielnicom. Na czele każdego okręgu miał stanąć radca miejski jako przewodniczący komitetu dzielnicowego. Zwrócono się też do Komendy Wojska Polskiego o przydzielenie reprezentanta celem utrzymania ciągłego kontaktu ${ }^{47}$. Do straży powoływano obowiązkowo mężczyzn niepodlegających służbie wojskowej. Do najważniejszych jej zadań należało: pilnowanie magazynów, utrzymywanie porządku na ulicach, zwalczanie pospolitej przestępczości i spekulacji4 ${ }^{48}$.

Oprócz wymienionych akt Magistratu, zawierających korespondencję związaną z funkcjonowaniem miasta czy sprawami bytowymi jego mieszkańców, w aktach władz miejskich zachowane są na ogół kompletne protokoły posiedzeń władz miejskich. Materiały te są nieocenionym źródłem wiedzy dotyczącej funkcjonowania miasta. Również w kwestii odzyskania niepodległości, tworzenia się organów władzy państwowej, władze miejskie nie pozostawały obojętne, czego wyrazem były gesty poparcia w postaci uchwał rad miejskich wyrażających gotowość poddania się tej władzy.

Dnia 12 października 1918 r. odbyło się 57. posiedzenie nadzwyczajne Rady Miasta Krakowa, w trakcie której prezydent Krakowa Jan Kanty Federowicz poinformował zgromadzonych o ogłoszonym przez Radę Regencyjną manifeście, proklamującym zjednoczoną niepodległą Polskę oraz o swym telegramie, wysłanym w geście poparcia. Rada miasta opowiedziała się za działaniami Rady Regencyjnej, uprawniając prezydenta miasta do przekazania wyrazów wsparcia „wraz ze złożeniem Jej hołdu i życzeń serdecznych, aby wierna swojemu obowiązkowi wraz z reprezentacyą całego narodu doprowadziła naród polski szczęśliwie i szybko do jego przyrodzonego celu, zjednoczenia i niepodległości. Niech żyje wolna niepodległa zjednoczona Polska!"49

${ }^{46}$ Przykładem może być sprawa z przechowywanego zespołu w ANK, 29/247/0 C.K. Dyrekcja Policji w Krakowie 1849-1919 [1926], sygn. 29/247/123, s. 1389-1390.

${ }_{47}$ Ibidem, 29/531/0 Straż Obywatelska w Krakowie [1912] 1918-1919 [1920], sygn. 29/531/44, Sprawozdania z posiedzeń Naczelnego Komitetu Straży Obywatelskiej w Krakowie zawiązanej w dniu 1/XI 1918, k.1.

${ }^{48}$ W Archiwum zachował się zespół Akta Straży Obywatelskiej w Krakowie z lat 1918-1919, liczący 129 j.a.

${ }^{49}$ Dziennik Rozporządzeń dla stoł. król. miasta Krakowa, Nr 10, Rocznik XXXIX [1918], s. $120-121$. 
W trakcie kolejnego 58. posiedzenia rady miejskiej, odbytego w dniu 7 listopada, prezydent Federowicz, w obecności generałów Tadeusza Rozwadowskiego i Zygmunta Zielińskiego, odniósł się do zmian, jakie nastąpiły 31 października i przejęciu pełni władzy cywilnej i wojskowej z rąk Austriaków. „Wszyscy stajemy do szeregów do pracy, która nas czeka. Niestety stolica nasza Warszawa nie jest jeszcze wolną od pęt dławiących ją od 100 lat - nie wrócili ci, którzy przy budowie ojczyzny są tak bardzo potrzebni. To też będę wyrazem uczuć wszystkich, gdy imieniem prezydium wniosę: Rada stoł. król. wolnego m. Krakowa uchwala zwrócić się do najwyższych rządzących czynników polskich $\mathrm{z}$ gorącą prośbą, by nie ustawały $\mathrm{w}$ dalszych ustawicznych dążeniach, zmierzających do uwolnienia Józefa Piłsudskiego" ${ }^{50}$.

Przykładem może tu również posłużyć protokół XV posiedzenia Rady Miasta Tarnowa z dnia 30 października 1918 r., w którym: „Przewodniczący stawia wniosek: Rada m. oświadcza, że Tarnów oddaje się poleceniom rządu warszawskiego - i że organowi rządowemu utworzonemu przez Radę regencyjną da posłuch. Rada nagłość wniosku oraz meritum uchwaliła"51.

W aktach Magistratu krakowskiego odnaleźć można też ciekawe materiały dotyczące obchodów kolejnych rocznic odzyskania niepodległości lub innych wielkich wydarzeń politycznych o fundamentalnym znaczeniu dla państwa i narodu. Są też tzw. akta wojenne z lat 1914-1918 [1919], zawierające głównie akta spraw prowadzonych przez Magistrat, związanych z funkcjonowaniem miasta i jego mieszkańców, ale też notatki, np. o zwiększonym napływie wojska do miasta w październiku 1918 r. ${ }^{52}$, obszerną korespondencję z PKL dotyczącą kwestii aprowizacyjnych, bezpieczeństwa publicznego, unormowań w zakresie obrotu towarami ${ }^{53}$.

Innym ciekawym źródłem do badań są pamiętniki, będące żywą, często bieżącą relacją - komentarzem do wydarzeń. Przykładem mogą tu służyć pamiętniki Aleksandry Czechówny ${ }^{54}$, prowadzone przez bardzo długi czas, bo w latach 1856-1923, obejmujące łącznie 44 tomy. Relacje dotyczące wojny oraz procesu odzyskiwania niepodległości były pisane u schyłku jej życia, dają dość rzeczowy obraz egzystencji mieszkańców miasta, ich nastrojów, opatrzone są ciekawymi komentarzami ówczesnej mieszkanki Krakowa. Warto w tym miejscu przytoczyć kilka z nich.

\footnotetext{
${ }^{50}$ Ibidem, s. 131-132.

${ }^{51}$ ANK Oddział w Tarnowie, 33/1/0 Akta miasta Tarnowa 1831-1944, sygn. 33/1/0/-/28 Protokoły Rady Miejskiej, 1918.

${ }_{52}$ ANK, 29/33/0 Akta miasta Krakowa..., sygn. 29/33/0/3.1.20/IT 956, Akta wojenne..., fasc. IV, s. 730 .

${ }^{53}$ Ibidem, s. 833-835, 1185-1188.

${ }^{54}$ W 1925 r., a zatem dwa lata po śmierci autorki, do Archiwum Aktów Dawnych w Krakowie zostały przekazane 44 zeszyty z zapiskami Aleksandry Czechówny.
} 
Wpis z piątku 1 listopada 1918 r.: „Wczoraj np. był bardzo ważny i prawdziwie historyczny dzień dla Krakowa. - Bez żadnej rewolucji i zamieszania, pozrzucano orły austriackie, a umieszczono polskie. Z odwachu ustąpiła dobrowolnie załoga austryacka, a objęło takowy wojsko polskie, nad którym w Krakowie objął komendę brygadier Roya. Jak dotąd wszystko odbywa się bardzo spokojnie i porządnie" 55 .

Wpis z poniedziałku 4 listopada 1918 r.: „Dzień każdy przynosi coraz to nowe wiadomości, ale ostatnie są smutne. Ukraińcy i Rusini zajęli Lwów, Przemyśl i inne miasta. Jednem słowem chcą zabrać wschodnią Galicyę, ale mam nadzieję, że Wilson inaczej rozporządzi. W Wiedniu podobno anarchia i właściwie nie ma kto rządzić, gdyż wszyscy ministrowie podali się do dymisji. U nas w Krakowie jak dotąd porządek i ład, gdyż straż obywatelska czuwa nad miastem, utrzymuje porządek, jak również i starsi studenci" ${ }^{\prime 56}$.

Wpis z piątku 8 października 1918 r.: „Dziwna to doprawdy epoka w jakiej żyjemy. $Z$ jednej strony szczęście i spełnienie wszystkich naszych marzeń, ale z drugiej teraźniejszość pełna grozy i obaw. Najsmutniejsze jest to, że nie ma między nami Polakami jedności. Różne partye ścierają się między sobą, i nienawidzą tak jak największych nieprzyjaciół. Wszyscy chcą rządzić, a nikt słuchać, a jako najgłośniejsze hasło rozlega się, że Polska musi być ludowa i socyalistyczna, inaczej nie chcemy!" 57

Bardzo cenny materiał źródłowy do badań dają nam spuścizny, wśród nich jako przykład można wskazać Spuściznę Karola Rolle ${ }^{58}$, wiceprezydenta i prezydenta Krakowa, uczestnika wielu zdarzeń z lat 1914-1918 oraz okresu międzywojennego. W części dotyczącej okresu odzyskiwania niepodległości są to przede wszystkim dokumenty osobiste, różnego rodzaju rozkazy, pozwolenia (np. do podróżowania) wydawane przez Polską Komisję Likwidacyjną w związku z wykonywanymi czynnościami, zaproszenia, banknoty o różnych nominałach. W części tej zachowało się też kilka listów adresowanych do PKL, zawierających ciekawy wątek rozliczenia działalności antypolskiej w czasie wojny, zabezpieczenia archiwum austriackiego wojskowego oddziału wywiadowczego w Krakowie. Jeden z nich, niedatowany, skierowany do Wydziału wojskowego PKL przez Alfreda Szołayskiego zawiera uwagę, iż ,jest rzeczą z wielu względów wskazaną, aby archiwum to zostało jak najrychlej poddane wyczerpującemu zbadaniu i opracowaniu" 59 . Autor zgłosił jednocześnie akces do tego przedsię-

${ }^{55}$ ANK, 29/1582/0 Spuścizna Aleksandry Czechówny [1763] 1856, sygn. 29/1582/0/-/42 Dziennik Aleksandry Czechówny, s. 226-227.

${ }^{56}$ Ibidem, s. 230.

57 Ibidem, s. 231.

${ }^{58}$ Biogram Karola Rolle (1871-1954), [w:] PSB; hasło oprac. Cz. Brzoza, t. 31, Wrocław-Warszawa-Kraków-Gdańsk-Łódź 1988-1989, s. 567-570.

${ }^{59}$ ANK, 29/1584/0 Spuścizna Karola Rolle 1864-1949, sygn. 29/1584/0/-/1, s. 1165. Pismo niedatowane, skierowane przez dr. [Alfreda] Szołayskiego do Wydziału wojskowego Polskiej Komisji Likwidacyjnej w Krakowie. 
wzięcia w imieniu swoim i Klemensa Bąkowskiego. W odpowiedzi z 20 listopada 1918 r., podpisanej przez naczelnika wydziału Włodzimierza Tetmajera, możemy przeczytać, iż PKL sprawą się zajęła, oddelegowała do działań „trzech Panów zaufanych", a oferowaną pomoc jest chętna przyjąć w terminie późniejszym $^{60}$. W odręcznym komentarzu do pisma Bąkowski napisał: „Tymczasem 2 razy się włamano i wykradziono część aktów, nikt należycie nie pilnował"61.

Kolejne pismo, tym razem przygotowane przez Bąkowskiego, było wsparciem stanowiska wyrażonego przez Szołayskiego, stanowiło odpowiedź na list Tetmajera z 20 listopada 1918 r., a dotyczyło kwestii zabezpieczenia dokumentów archiwalnych oddziału wywiadowczego byłej komendy austriackiej w Krakowie. Otóż domagał się on, by dokumenty ,zostały zabezpieczone w sposób praktykowany co do ważnych archiwaliów w bibliotekach i archiwach wszystkich cywilizowanych krajów"62. Wymienił sposoby zabezpieczenia dokumentów, wyjaśnił także motywy podejmowania takich działań następująco: „Do aktów powyższych przywiązujemy wielkie znaczenie, ponieważ w epoce 1914/1915, kiedy prawie wszyscy posłowie Galicyjscy uciekli, nas tu pozostałych trapiono podsłuchiwaniami, donosami, przesłuchiwaniami i aresztowaniami, dlatego zależy nam na wyszukaniu autorów denuncyacyj” ${ }^{63}$. Inne pismo z 12 grudnia 1918 r., skierowane do PKL, zawierało podobne postulaty: „Po rozłączeniu się pojedynczych narodów Państwa austr. oprócz urzędowego obrachunku terrytoryów, pozostaną pretensye pojedynczych obywateli do rozmaitych zbrodniarzy wojskowych i cywilnych [...] Tacy wieszatele jak arcyksiążęta Fryderyk i Józef Ferdynand, rozmaici generałowie itd. muszą być pociągnięci do odpowiedzialności. Wszystkie wyroki sądów wojsk. muszą być zrewidowane i ewentualnie unieważnione o ile się okażą braki formy przepisanej, braki istoty czynu, dowodów lub inne nadużycia" ${ }^{64}$. Wątek ten powraca w piśmie skierowanym przez Bąkowskiego do Ministerstwa Sprawiedliwości, a dotyczącym sprawy zwrotu szkód wojennych i wydania zbrodniarzy wojennych w myśl traktatów pokojowych $^{65}$.

Uzupełnieniem do badań mogą być materiały zgromadzone w zbiorze Akta osób i rodzin - zbiór szczątków zespołów z lat 1288-2019. Składają się na nie m.in. przekazane bądź zakupione do zasobu Archiwum akta legionistów, żołnie-

${ }^{60}$ Ibidem, s. 1163. Pismo Naczelnika Wydziału wojskowego PKL W. Tetmajera oznaczone L.: 89/a z 20 XI 1918 r., adresowane do dr. Alfreda Szołayskiego.

${ }^{61}$ Ibidem, s. 1163. Pismo Naczelnika Wydziału wojskowego PKL W. Tetmajera oznaczone L.:

89/a z 20 XI 1918 r., adresowane do dr. Alfreda Szołayskiego, dopisek odręczny pod tekstem.

${ }^{62}$ Ibidem, s. 1155-1156.

${ }_{63}$ Ibidem, s. 1171.

${ }^{64}$ Ibidem, s. 1167-1169. Pismo z dnia 12 grudnia 1918 r. K. Bąkowskiego do Polskiej Komisji Likwidacyjnej.

${ }^{65}$ Ibidem, s. 1175. Pismo niedatowane, na marginesie autor zapisał odręcznie datę ekspedycji11 X 1919 r. 
rzy z okresu walk 1914-1918 i 1918-1921. Są to bardzo ciekawe relacje uczestników zdarzeń, spisanych w różnych okresach ich życia ${ }^{66}$.

Komplementarne względem dokumentów aktowych są też fotografie przechowywane w Zbiorze fotograficznym, a także plakaty, afisze, odezwy, obwieszczenia, zawiadomienia, ogłoszenia zgromadzone w Zbiorze afiszy i plakatów.

Bardzo ciekawe materiały ilustracyjne (druki, akwarele, litografie) stanowią Zbiór Ikonograficzny Jana Augustyna z lat 1794-1934, drukarza krakowskiego. Są one istotnym dopełnieniem materiałów aktowych, cennymi materiałami ekspozycyjnymi, dziełami sztuki drukarskiej.

Uzupełnieniem materiałów aktowych w badaniach nad odzyskaniem niepodległości w Krakowie będą też tytuły prasowe - przede wszystkim „Czas”, „Ilustrowany Kuryer Codzienny” i „Nowości Ilustrowane”.

Podsumowując wyniki przeprowadzonej kwerendy, należy stwierdzić, że Archiwum Narodowe w Krakowie posiada w swym zasobie stosunkowo wiele materiałów źródłowych do badań nad wydarzeniami związanymi z odzyskaniem przez Polskę niepodległości i to wielu jego aspektów. Są to zarówno materiały dotyczące zagadnień politycznych, jak i wojskowych, choć zasadniczą część zgromadzonych materiałów archiwalnych stanowią relacje uczestników zdarzeń. Badacze zagadnień walk niepodległościowych na ziemiach polskich chętnie je wykorzystują.

\section{Źródła}

Archiwum Narodowe w Krakowie

29/33/0 Akta miasta Krakowa [1227] 1300-1945 [1975], sygn. 29/33/0/3.1.20/IT 924 Akta wojenne Magistratu miasta Krakowa, fasc. II., sygn. 29/33/0/3.1.20/IT 956 Akta wojenne Magistratu miasta Krakowa, fasc. IV.

29/207/0 Archiwum Urzędu Wojewódzkiego Krakowskiego - zbiór szczątków zespołów [1810] 1877-1952.

29/247/0 C.K. Dyrekcja Policji w Krakowie 1849-1919 [1926], sygn. 29/247/2, 29/247/123.

29/531/0 Straż Obywatelska w Krakowie [1912] 1918-1919 [1920], sygn. 29/531/44.

29/645/0 Akta osób i rodzin - zbiór szczątków zespołów 1288-2019, sygn. 29/645/75 Akta rodziny Dziatkiewiczów, sygn. 29/645/131 Akta legionowe Mieczysława Klötzera i Zygmunta Kowalskiego, sygn. 29/645/317 Papiery rodziny Wyrodów, sygn. 29/645/393 Różne dokumenty i odznaczenia Tadeusza Karola Kucza, oficera Legionów Piłsudskiego, pułkownika Wojska Polskiego, dra weterynarii.

29/665/0 Zbiór afiszy i plakatów 1825-1949 [1964].

${ }^{66}$ Na szczególną uwagę zasługują zebrane w zbiorze ANK, 29/645/0 Akta osób i rodzin - zbiór szczątków zespołów 1288-2019, sygn. 29/645/75 Akta rodziny Dziatkiewiczów, sygn. 29/645/131 Akta legionowe dotyczące szczególnie Mieczysława Klötzera i Zygmunta Kowalskiego, sygn. 29/645/317 Papiery rodziny Wyrodów, sygn. 29/645/393 Różne dokumenty i odznaczenia Tadeusza Karola Kucza, oficera Legionów Piłsudskiego, pułkownika Wojska Polskiego, dra weterynarii. 
29/667/0 Prace naukowe, literackie i pamiętniki - zbiór szczątków zespołów 1401-2002, sygn. 29/667/28.

29/669/0 Varia publica - zbiór szczątków zespołów 1502-1972.

29/670/0 Zbiór fotograficzny poł. XIX w. - 1997.

29/673/0 Zbiór ikonograficzny Jana Augustyna 1794-1934.

29/1582/0 Spuścizna Aleksandry Czechówny [1763] 1856, sygn. 29/1582/0/-/42.

29/1584/0 Spuścizna Karola Rolle 1864 - 1949, sygn. 29/1584/0/-/1.

Archiwum Narodowe w Krakowie Oddział w Tarnowie, 33/1/0 Akta miasta Tarnowa 1831-1944, sygn. 33/1/0/-/28 Protokoły Rady Miejskiej 1918.

Biblioteka Jagiellońska, rkps 7285, Dziennik Klemensa Bąkowskiego.

Dziennik Rozporządzeń dla stoł. król. miasta Krakowa, Nr 10, Rocznik XXXIX [1918].

\section{Bibliografia}

Bąkowski K., Kronika Krakowa od 1918 do 1923, Kraków 1925.

Buszko J., Polska Komisja Likwidacyjna, [w:] Problemy historii Stowian i Europy Środkowej w XIX i XX wieku. Zbiór studiów, Wrocław 1982, s. 25-37.

Chmiel A., Oswobodzenie Krakowa 31 października 1918 roku, Kraków 1929.

Daszyński I., Pamiętniki, t. 1, Kraków 1925.

Estreicher K., Nie od razu Kraków zbudowano, Warszawa 1956.

Kraków w latach 1918-1939, Dzieje Krakowa, pod. red. J. Bieniarzówny, J.M. Małeckiego, t. 4, Kraków 1997.

Kubalski E., Kraków w czasie Wielkiej Wojny, wstęp i red. nauk. M. Zakrzewski, Kraków 2018.

Lasocki Z., Wspomnienia szefa administracji P.K.L. I K. Rz., Kraków 1931.

Listopad 1918 we wspomnieniach i relacjach, wybór, oprac. i wstęp P. Łossowskiego i P. Staweckiego, Warszawa 1988.

Moje wspomnienia. Wincenty Witos, do druku przygotowali, przedmową i przypisami opatrzyli E. Karczewski, J.R. Szaflik, cz. 1, Warszawa 1998.

Łossowski P., Jak feniks z popiołów. Oswobodzenie ziem polskich spod okupacji w listopadzie 1918, Łowicz 1998.

Mroczek L., Galicji rozstanie z Austrią. Zarys monograficzny, Kraków 1990.

Mroczek L., Spór o Galicję Wschodnia 1914-1923, Kraków 1998.

Nowak J.T., Wieża Wolności 1918. W 90. rocznicę wyzwolenia Krakowa, Kraków 2008.

Nowak J.T., Wieża Wolności 1918. W 100. rocznicę wyzwolenia Krakowa, Kraków 2018.

Pamiętnik Hermana Diamanda, zebrany z wyjątków listów do żony, wstęp S. Loewenstein, Kraków 1932.

Polski stownik biograficzny, tomy: 3(1937), 4(1938), 16(1971), 31(1988/89), 38(1997/98), 42(2004).

Przeniosło M., Narodziny niepodległości Galicji (1918-1919). Wybór źródeł z archiwów lwowskich, Kielce 2007.

Przeniosło M., Polska Komisja Likwidacyjna 1918-1919, Kielce 2010. 
Przyboś K., Dwie relacje Tadeusza Szantrocha - o Krakowie w 1914 i o oswobodzeniu Krakowa 31 października 1918 roku „Rocznik Krakowski” 1987, t. 53, s. 158.

Roja B., Legendy i fakty, Warszawa 1931.

Stawarz A., Gdy Kraków kruszyt pęta. Kartki z pamiętnika oswobodzenia Krakowa w 1918 r., wstępem i objaśnieniami opatrzył J. Czapliński, Kraków 1939.

Śliwa M., Pierwsze ośrodki władzy polskiej w Galicji w 1918 r., „Dzieje Najnowsze” 1988, nr 4, s. $63-73$ 